\title{
Como a equipe interdisciplinar e a família influenciam no tratamento de mulheres com câncer de mama ${ }^{1}$
}

Mariana da Silva Pereira Reis ${ }^{2}$

Sergio Henrique de Souza Alves ${ }^{3}$

\section{Resumo}

A palavra “câncer” sempre foi assustadora. Quando há referência a essa doença, logo surge a associação ao sofrimento e à morte. O diagnóstico tem um profundo impacto psicossocial nos pacientes e seus familiares, pois desagrega o funcionamento biopsicossocial da doente, conduzindo à necessidade de readaptação das suas vivências intrapsíquicas. A ansiedade nessas famílias e também na equipe intersciplinar é alta por ser a doença estigmatizada como sinônimo da possibilidade de morte e por ser a terapêutica muito agressiva com efeitos colaterais, mudança da auto-imagem, procedimentos médicos invasivos e estressantes, ocorrência de depressão e dor. Para a realização desta pesquisa, foram realizadas entrevistas semi-estruturadas com duas mulheres com câncer de mama, sendo posteriormente, transcritas e discutidas, com a finalidade de conhecer o funcionamento e as características das relações dessas três unidades (paciente, família e equipe hospitalar) aprofundando sobre o nível de conhecimento que cada portadora tem de sua doença.

Palavras-chave: Câncer de mama. Mulher. Família. Equipe interdisciplinar.

\section{Introdução}

Com tanta informação sobre o câncer, vê-se, no entanto, que ainda existe uma grande dificuldade entre o portador e seus familiares em conviver com esta doença de forma mais harmoniosa. Tendo em vista que o preconceito quanto ao

\footnotetext{
${ }^{1}$ Pesquisa realizada no Programa de Iniciação Científica do UniCEUB em parceria com o CNPq.

${ }^{2}$ Graduada em Psicologia pelo Centro Universitário de Brasília - UniCEUB, email: maryspr@gmail.com

${ }^{3}$ Doutor em Psicologia pela Universidade de Brasília - UnB.
} 
câncer ainda é exacerbado no meio familiar, em razão da falta de informação e pelo impacto negativo que algumas vezes causa desestruturação da pessoa e de sua família. Quanto à equipe hospitalar, já se vê uma grande mudança na estrutura com a entrada da equipe interdisciplinar, em troca da multidisciplinar, que, apesar de ainda estar em fase de transformação e adaptação em alguns hospitais, já vem mostrando perceptíveis melhoras no tratamento do câncer desde o choque do diagnóstico até o momento da cura (em alguns casos). Porém, toda a reestruturação ainda não foi realizada e, isso pode ser um agravante no tratamento tanto para o portador do câncer quanto para seus familiares. Por isso, julga-se importante o entendimento de como ambas as partes reestruturam-se para um tratamento mais adequado.

No caso do câncer de mama, um bom resultado no tratamento, além do tratamento no ambiente hospitalar, seria, com certeza, um bom apoio psicossocial no ambiente familiar de qual a portadora faz parte. Avaliar a paciente diagnosticada e submetida a tratamento por câncer de mama é questão importante e, muitas vezes, tarefa a cargo do oncologista, do cirurgião, da enfermeira ou dos demais membros da equipe multidisciplinar, já que raramente o psiquiatra ou o psicólogo entra em cena no início da abordagem. Uma questão que pode preocupar essa equipe multidisciplinar é a dificuldade em reconhecerem quadros psiquiátricos. Em geral, percebe-se a ocorrência de determinadas alterações psicopatológicas relacionadas à ansiedade e à depressão, mas raramente um diagnóstico amplo ou formal é feito.

O momento em que a mulher se depara com o diagnóstico de câncer, seu modo de vida e suas relações interpessoais passam a ser objetos de reflexão e questionamentos. Considerando que tal processo tem início com a descoberta da doença, torna-se importante atentar para esse momento e realizar uma análise acerca desse tipo de experiência. Trata-se de uma etapa peculiar da vida, na qual a mulher passa a assumir o papel de doente, além de todos aqueles anteriormente desempenhados por ela (VIEIRA; QUEIROZ, 2006).

[...] receber o diagnóstico de câncer pressupõe uma série de conseqüências que atingem diretamente o modo de vida do indivíduo. Algumas delas estão associadas ao aspecto social e familiar; outras, ao psiquismo, como as idéias recorrentes de morte, o medo de mutilação e da perda de algumas pessoas de seu convívio (Ferreira, citado em Vieira \& Queiroz, 2006, p. 64). 
A fim de verificar a ocorrência ou não de influência no tratamento de mulheres com câncer de mama, tanto dos profissionais de saúde como do ambiente familiar, foi realizado um estudo cujo objetivo foi de compreender e descrever como as experiências do diagnóstico e do tratamento do câncer de mama são vivenciadas pelas mulheres assistidas pela Associação Brasiliense de Apoio ao Câncer (ABAC), verificando se à relação com a família e a equipe do hospital em que fazem o tratamento influencia no modo como vêem e enfrentam a doença pelos seus familiares e pela equipe interdisciplinar. Para tanto foram utilizadas entrevistas semi-estruturadas, pois, segundo González Rey (2004) “as construções do sujeito diante de situações pouco estruturadas produzem uma informação qualitativamente diferente da produzida pelas respostas a perguntas fechadas", onde, o sentido da resposta estará sendo influenciado pela forma como é construída a pergunta pelo investigador.

Essas entrevistas seguiram um roteiro pré-determinado, no qual as perguntas eram feitas de acordo com as respostas trazidas por essas mulheres. Em alguns casos, viu-se a necessidade de acrescentar mais perguntas para que pudesse compreender melhor o que era trazido pela paciente; já em outros, viu-se a necessidade de suprimir algumas perguntas, pois às pacientes estavam trazendo mais informações do que o perguntado. González Rey (2006) retrata que a pesquisa nesse modelo não esgota o problema, mas gera novas zonas de sentido, abre novas possibilidades para a construção teórica com relação ao problema abordado.

Este estudo foi submetido à avaliação e aprovação do Comitê de Ética do Centro Universitário de Brasília - UniCEUB, e, foi apresentado como monografia ao final do primeiro semestre de dois mil e sete.

\section{Metodologia}

O processo de investigação nesta pesquisa está orientado por metodologia qualitativa que nos permite visualizar o problema a partir de perspectiva construtivo-interpretativa centrada no diálogo como momento de produção de conhecimento (VIEIRA; QUEIROZ, 2006). 
González Rey (2004) fala que toda pesquisa qualitativa deve implicar o desenvolvimento de um diálogo progressivo e organicamente constituído, como uma das fontes principais de produção da informação, criando climas de segurança, interesse, confiança e tensão intelectual para favorecer os níveis de conceituação da experiência que raramente aparecem de forma espontânea na vida cotidiana.

Ainda segundo González Rey (2004), a pesquisa qualitativa se diferencia da quantitativa por estar orientada à produção de idéias, ao desenvolvimento da teoria, e nela o essencial é a produção de pensamento, não o conjunto de dados sobre os quais se buscam significados de forma despersonalizada na estatística.

A pesquisa qualitativa não corresponde a uma definição instrumental, é epistemológica e teórica, e apóia-se em processos diferentes de construção de conhecimento, voltados para o estudo de um objeto distinto da pesquisa quantitativa tradicional em psicologia. A pesquisa qualitativa se debruça sobre o conhecimento de um objeto complexo: a subjetividade, cujos elementos estão implicados simultaneamente em diferentes processos constitutivos do todo, os quais mudam em face do contexto em que se expressa o sujeito concreto. A história e o contexto que caracterizam o desenvolvimento do sujeito marcam sua singularidade, que é expressão da riqueza e plasticidade do fenômeno subjetivo (GONZÁLEZ REY, 2004, p. 50-51).

Para a realização desta pesquisa, primeiramente, foi estabelecido contato com a Associação Brasiliense de Apoio ao Câncer - ABAC - tendo como finalidade a aproximação com as pacientes que procuram ajuda psicológica e estabeleceram vínculo com este local. Foi acordado com a ABAC que a mesma faria o primeiro contato com essas pacientes para explicá-las quais os objetivos deste estudo verificando, desta forma, o real interesse dessas pacientes em participar da pesquisa.

Após contato da ABAC, foi realizado um pré-contato, via telefone, com cada participante, com a finalidade de constatar o interesse em participar deste projeto de pesquisa, explicando qual a finalidade do mesmo. Durante as conversas telefônicas, caso a paciente mostrasse interesse em participar da entrevista, era agendada uma visita em sua residência para a realização da entrevista semi-estruturada.

Foram realizadas duas entrevistas semi-estruturadas com duas mulheres portadoras de câncer de mama utilizando-se de um MP3 da marca "Foston Digital Life” para a gravação. A entrevista semi-estruturada caracteriza-se como um con- 
tato face a face com o entrevistado, com o qual se estabelece uma conversação a partir de um roteiro elaborado previamente. Como este roteiro é aberto, permitiuse que outras questões fossem levantadas durante o desdobramento da entrevista.

Antes de dar início a cada entrevista, foram entregues às participantes dois termos de consentimento livre e esclarecido, onde um ficaria em posse da participante e o outro, em posse da pesquisadora. Este termo foi lido junto com a paciente, e, antes que esta assinasse o termo, foi aberto para quaisquer perguntas para que não restasse nenhuma dúvida sobre a pesquisa. Sendo esclarecido tudo, a paciente assinou o termo, e, foi dado início a gravação da entrevista.

Ao final de cada entrevista, foi acordado com cada entrevistada que, ao término deste estudo elas estariam recebendo um retorno sobre os resultados alcançados.

As variáveis foram estudadas levando-se em consideração a fase do câncer de mama de cada entrevistada.

\section{Resultados e discussão}

Foram realizadas, transcritas e analisadas duas entrevistas semi-estruturadas com mulheres que tiveram o diagnóstico de câncer de mama. As participantes foram identificadas por sujeito 1 e sujeito 2 respectivamente. Por coincidência, todas as participantes são estudantes de psicologia; e, ser estudante de psicologia não foi considerado pré-requisito para a participação neste estudo. Todas residem em Brasília e, as entrevistas foram realizadas em suas residências.

O fato de todas as participantes serem estudantes de psicologia pôde ser percebido como influência, de certa forma, durante o processo, pois, todas mencionaram algum fator onde agradeciam poder estar cursando psicologia, pois achavam que o curso as estava ajudando de alguma forma no enfrentamento.

As entrevistas foram realizadas no ano de 2007.

1 é uma mulher de 56 (cinqüenta e seis) anos, e teve seu câncer de mama diagnosticado em abril de 2006, como ela mesma retrata abaixo: 
[...] meu câncer de mama foi diagnosticado em abril do ano passado... quem descobriu fui eu... eu tinha ido no médico uma semana antes... na semana anterior e ele não percebeu nada... e... inclusive eu cheguei a pedir pra ele que ele solicitasse uma ecografia de mama porque no... há um ano antes eu tinha feito a mamografia... então eu achava que podia pedir só uma ecografia... e ele pediu... e eu descobri o câncer de mama exatamente um dia antes de fazer a ecografia. Aí eu descobri o nódulo e... eu fiquei... eu fiquei muito assustada e... e no outro dia eu fui fazer o... a ecografia... e o médico disse... apenas dizia "ele não podia ta desse tamanho"... e eu... eu não gostei muito... eu tava... eu acho que eu não queria perceber o que que tava acontecendo... aí ele disse que eu deveria fazer uma mamografia... e... ele mesmo me deu a requisição... e... me indicou a médica... e eu fui... eu consegui fazer no mesmo dia a mamografia também... e ela me disse que as mamografias, normalmente o resultado é em quatro dias mas pra você eu vou entregar amanhã cedo... e... eu vim me embora... e no outro dia eu fui pra buscar o resultado e... e tava escrito que... era maligno... que tinha todo sintoma de malignidade... mas que era... normal... por se tratar de um câncer... é... quando eu li aquilo... meu mundo realmente desmontou... desmoronou todo...

Pode-se retratar o que acontece com 1 citando Camon (2001), que diz: "não é a dor que a doença traz que incomoda, é algo mais subjetivo: é a dor de saber-se doente, de perder a condição de sadio". E, ele continua seu raciocínio da seguinte forma: "Para o doente crônico existe a constante ameaça de deterioração, desvalorização e destruição: uma ameaça de aniquilamento, o que provoca labilidade das emoções; e, mais do que isso, o sofrimento imaginado pode se tornar mais importante do que o risco real orgânico”.

Também se percebe que representação ela tinha do câncer; pois, o câncer trouxe um sentimento de medo com a sensação de o mundo estava se desmoronando. Abaixo, seguem partes de sua fala que demonstra melhor essa situação:

... eu... eu entrei em crise... eu não sabia o que que eu fazia... eu... eu não sabia a... pra que lado ir... eu me preparei pra morrer... eu fiz uma faxina nas minhas roupas... e... já comecei a juntar roupa pra dar... já comecei a... limpar coisas e... entrando dentro de casa... e chorando... eu fiquei muito desesperada, porque pra mim... a idéia que eu tinha era só de que... o câncer mata... 
Segundo Moraes (2003), o diagnóstico de câncer é freqüentemente acompanhado de depressão, a qual é traduzida pelo fato de o paciente não conseguir manter uma atitude de aceitação então, não conseguindo negar a doença, se vê obrigado a reconhecer que tem um câncer, o que fica claro na fala de 1, quando ela diz que se preparou para morrer e que começou a juntar suas coisas.

Costa (1999) nos mostra que a palavra "câncer" sempre foi assustadora. Quando há referência a essa doença, logo surge a associação ao sofrimento e à morte; e, tais comportamentos aumentam a desinformação e dificultam o tratamento, pois o diagnóstico precoce é a grande arma no tratamento da doença. Que volta a aparecer na fala da participante quando relata que:

Eu não sabia nada a respeito e, uma coisa interessante é que nós não... que a gente só grava aqueles casos que não deram certo... Você só escuta "morreu um fulano" "morreu o outro", entendeu? Então, o medo de morrer é muito grande. Sabe... o medo de morrer é muito grande.

Percebemos nesta fala um sentimento de angústia e sofrimento perante a doença. Sua percepção parece ser seletiva para os casos com um desenvolvimento negativo; o que Moraes (2003) seria um mecanismo de defesa. O mesmo autor também retrata que o diagnóstico de câncer é freqüentemente acompanhado de depressão, onde o paciente não consegue manter uma atitude de aceitação interior, ou seja, não conseguindo negar a doença, vê-se obrigado a reconhecer que a tem e acaba se deprimindo diante de acontecimentos variados sobre o mesmo assunto.

Em relação à participação da equipe, quando perguntamos de qual forma ela percebeu a equipe do hospital em seu tratamento, se a ajudou a lidar melhor com a situação. Ela responde a esta pergunta descrevendo os acontecimentos e, trazendo, também, o que ela sentia.

[...] Você sabe quem é um ginecologista bom, mais você não sabe quem é um mastologista bom... E... foi o meu ginecologista que me indicou ele... e... eu acho que... pelo menos comigo... eles não têm muito tato em tratar desse assunto... sabe? Eu... por exemplo, ele disse... você vai ser operada... e... não precisa tirar o seio, mas... eu também não tava muito preocupada com isso... Você fica tão desesperada que não é isso que te preocupa... e... mas aí eu aliviei. Eu aliviei porque vai ser operada e coisa e tal... ai eu fui lá um dia e ele me disse que a senhora vai ser operada e trinta dias depois começa a radioterapia e a quimioterapia... aí eu desabei... desabei... desabei... 
Alguns autores como Wanderley (2003), retratam em seus estudos que a mama seria um dos símbolos da feminilidade, ou seja, sua retirada pode alterar a auto-imagem da paciente com cancer de mama, trazendo sentimentos de inferioridade e medo de ser rejeitada; porém, podemos perceber que na fala de 1, a perda da mama não pareceu ter tanta significância. Não podemos dar uma causa específica para isso; mas, podemos relacionar sua fala ao fato de ainda estar em choque com o diagnóstico, onde o medo da morte ainda é maior que o medo do que ainda pode acontecer ou não, ou ainda, podemos relacionar com o fato de ser uma mulher sozinha, que, talvez, não se preocupe tanto com a aparência de seu corpo. Dentre essas afirmações, a primeira pareceu mais lógica, pois, nossa participante estava vivenciando seus primeiros momentos de diagnóstico e, recebendo muitas informações de uma só vez.

Sua fala nos mostra o medo da doença junto à negação inicial de estar doente, o não querer perceber que estava doente. Moraes (2003) nos diz que "o paciente oncológico, angustiado pelo medo da morte, fica voltado para si mesmo ou utiliza mecanismos de defesa"; neste caso, o mecanismo de defesa seria a negação do estar doente.

Em contrapartida, sua fala, também nos mostra, rapidamente, sua constatação da perda da saúde.

Porque aí, a idéia que eu tinha de câncer era aquele filme "Tudo por amor", o que vinha era só aquilo... era aquele rapaz passando mal... mais uma vez eu estava sozinha... quando ele diz isso pra mim... e eu saio de lá... mais eu chorava tanto, mais tanto... quando ele terminou de me dizer, daí eu disse pra ele, "mas o senhor não tem nada de bom pra me dar? Pra me dizer?", e ele disse "Não senhora... não tem nada". Daí eu disse, "então me dá remédio pra eu dormir”... e ele deu... e eu sai de lá... mais eu chorava tanto, mais tanto... eu entrei dentro do carro... e eu não dava conta de sair com o carro... Porque eu acho que a cada dia eu tomava mais consciência da doença de uma forma ou de outra... Porque ali foi a constatação de que realmente eu tava doente... Não era só operar que iria acabar a história... Você vai ser operada e vai começar a história... Porque eu acho que até ali, eu tinha programado que ia operar e acabou... Mas não... não era... Foi desesperador[...] 
Sua constatação da doença veio junto da percepção de que o tratamento não iria ser rápido. Então, podemos perceber que nossa participante já tinha um "préconceito" sobre o que aconteceria durante o tratamento. A negação do tratamento pode ter sido uma fuga da realidade. $\mathrm{O}$ pacto inicial mostra um desespero com a constatação e angústia de que não acabaria rápido o processo. A operação seria apenas o primeiro passo e ela a percebe como o ponto inicial de um sofrimento sem, ainda, vivenciá-lo.

Podemos perceber, também, nesta fala, o posicionamento do médico que a atendeu. Um comportamento que podemos significá-lo como desumano; porém, não temos conhecimento de todo o contexto desta consulta, mas, apenas a visão de 1, ou seja, estamos com apenas "meia verdade" sobre a situação. Segundo Chiattone (1998) os médicos em vez de tratarem de pacientes que estão doentes concentram suas atenções no tratamento das doenças. O que, nesta situação, parece ter sido verdade.

Ela continua nos respondendo sobre a equipe que a atendeu, como segue:

Então... um mês depois eu fui operada... sem problemas... aí depois eu fiz a quimioterapia... já foi... sugestão de uma colega da médica... que foi a médica que tratou da mãe dela... apesar da mãe dela ter morrido... quer dizer... eu gostei da maneira como ela fala dessa médica... me indicaram uma outra médica aqui em Brasília... eu não quis porque a pessoa que me indicou a médica... ela disse o seguinte... que... a médica era muito boa... e que o pai dela quando teve muito mal... que a médica viu que o pai dela não tinha mais como... sarar... que ele ia começar a sofrer muito... ela induziu o coma e ele morreu... então... pra mim essa médica não serve... eu não quis nem conhecer... Aí eu fui pra essa outra médica... e lá eu gostei de mais dela... ela te passa assim... ela não te ilude... eu vi que hoje não existe mais de iludir o paciente... hoje se sabe tudo... então ela... ela me disse que é isso mesmo... o seu cabelo vai cair... você vai engordar... e você vai fazer o tratamento... vai ser de vinte em vinte um dias... e depois eu comecei o tratamento... foi muito bom... é uma equipe fantástica... são pessoas muito humanas... são pessoas muito carinhosas... que estão ali... é um negócio muito legal... porque você ta muito fragilizado... e eles te tratam com muito carinho...

Percebe-se em sua fala uma transferência de papeis do médico. A escolha do médico foi feita a partir do que ela achava ser correto em um tratamento. A 
médica citada como a que induziu um coma durante o tratamento por ver que não existia uma cura, fez com que ela não a procurasse. Sua fala demonstra ainda o medo da morte; talvez, ser atendida por essa médica poderia estar significando morte. $\mathrm{O}$ profissional escolhido foi visto como bom por tratar a realidade, que, segundo ela, "não existe mais de iludir o paciente".

Ela se refere à equipe da quimioterapia como sendo muito acolhedora, e, isso parece ter ajudado a enfrentar este processo de uma melhor forma. E, ela continua sua fala sobre a equipe, falando também, um pouco mais sobre seu tratamento:

E eu sofri de mais aqui em casa... eu não engordei... eu emagreci muito [...] depois eu terminei o tratamento... ai eu fui fazer a radioterapia... também é um lugar assim... onde você já encontra mais pessoas no mesmo tratamento... pessoas amáveis... pessoas solidárias... todos ali tem o mesmo problema... todos estão tratando ou de um tipo ou de outro de câncer... então você conversa abertamente sobre o seu cabelo que caiu... sobre a peruca... sobre... como é que você está... então... há muita confiança... então eu gostava muito do ambiente lá com as pessoas... os profissionais eles me ajudaram muito... a enxergar... que... você não precisa dizer nada pra pessoa... não existe essa de querer... é... consolar a pessoa... nós não queremos ser consolados! Mas, nós também não queremos ser maltratados... são pessoas honestas... e são pessoas... que... mas eu estou aqui... sabe? É... é aquela... prontidão com que eles te atendem... por exemplo, eu tive uma dor de cabeça na faculdade... voltei pra casa... e liguei lá na... na oncologia... e falei com o chefe da enfermaria... eu disse "eu tive dor de cabeça... voltei pra casa... e não sei o que que eu faço", aí ele me disse que "pega o meu telefone celular, pega o telefone da minha casa e o telefone da minha namorada e o da minha irmã...se você tiver febre, me localize em qualquer um desses telefones"... então... quer dizer... eu fiquei tranqüila... então... isso aí... te dar assim... sabe aquela coisa? Eu estou aqui! Não é a minha profissão... eu estou aqui... estou aqui por você... e para te acolher e te ajudar... eu gostei muito! ... mas... em contra partida... eu encontrei uma médica que... falaram pra mim que eu ia fazer... radioterapia primeiro que a quimioterapia... e eu paguei a consulta... de duzentos reais a consulta... pra poder falar com ela... ela fez de conta que tava fazendo uma entrevista... mais ela falava com todo mundo... sabe aquela hora que você percebe que a pessoa não ta prestando atenção? Você para de falar e a pessoa... não percebe que você parou de falar... então ela terminou ali 
a consulta... pediu um monte de exames... inclusive ela me pediu um exame do corpo todo... é uma... tomografia... essa tomografia fica em mil e oitocentos reais... o meu convênio pagou... mais eu não precisava daquela tomografia... então... ela me pediu aquilo e... terminou dizendo o seguinte "não é radiologia... você vai fazer primeiro a quimioterapia" aí eu sai de lá... eu comecei a chorar porque eu pensei... enquanto eu faço a radioterapia eu me preparo pra quimioterapia... e aí deu o contrário... eu não tinha como me preparar... o meu cabelo já vai cair... eu já vou começar a passar mal... aí eu sai de lá e no outro dia eu voltei pra poder fazer aquela tomografia que ela pediu... e eu encontrei com ela e eu disse pra ela "doutora, eu... eu paguei a consulta pra senhora... de duzentos reais... e eu não vou fazer a radioterapia agora... então... como eu vou fazer a quimioterapia... quando eu fizer a quimioterapia... eu voltar pra fazer a radioterapia... é... a senhora... aqueles duzentos reais da consulta... porque meu convênio só cobre o tratamento e não paga o médico... já ficaria o dinheiro por conta... da próxima consulta?" daí ela disse "não! Você tem que pagar nova consulta!"... eu disse "sim! Mas a senhora me atendeu e não era com a senhora! A senhora não podia ter me atendido... a senhora já sabia que não era com a senhora!" ela disse "não... mas eu te dei tempo... eu fiquei com você na sala... você pagou aquela e você vai pagar a próxima!"... eu achei desumano... eu achei anti-ético... e eu guardo... essa tomografia... que eu tenho aqui em casa... pelo seguinte... meu convênio pagou mais existem muitas pessoas que não tem convênio... é uma doença assustadora... é uma doença que você faz qualquer coisa pra salvar uma pessoa da família... então eu fico imaginando... uma pessoa... um pai... que uma pessoa dessa pedisse um exame daquele... ela já me cobrou os duzentos reais... ela já me cobrou aquela tomografia... e nada daquilo eu precisava... então... será que ela faz isso com todo mundo? Será que as pessoas já não tão agredidas o suficiente? Eu fiquei muito decepcionada com aquela médica... muito... é tanto que... quando eu voltei pra fazer a quimioterapia... eu não quis fazer com ela... então... teve isso... mas o resto do pessoal da radiologia... também... é... mais na radiologia... você não tem muito... o pessoal das máquinas lá... os técnicos de radiologia... são excelentes... são pessoas "bom dia"... "A senhora ta boa? Como a senhora ta bem... é... a senhora já ta terminando..." ...Então... eles te tratam assim... você sente uma pessoa amiga... taram pelo nome... eu disse pra um deles... a escolha de vocês para essa profissão foi uma escolha... perfeita... são pessoas que estão preparadas pra tratar desse assunto... onde eu fiz a oncologia... lá eles têm 
uma... uma nutricionista que te acompanha... então eu fiz tratamento com ela também... e... e... foi a partir dela... é que eu soube... é... você não pode... é... por exemplo... as outras pessoas não... mas, você... evitar o máximo possível churrasco na brasa... evitar alimentos guardados e Somoza... vidros conserva... evitar é... carne guardada no sal... charque...é... bacalhau... evita porque tudo isso é cancerígeno... pras outras pessoas isso não vai fazer mal... mas pra você, isso é problema... porque o seu corpo já aprendeu como criar uma doença... então... ela dizia pra mim... você não pode subir o seu colesterol... de jeito nenhum... é... você não pode deixar que o seu triglicerídeo suba... a partir de agora você vai virar... a guardiã disso daí... e... e ela me explicou... então ela disse... o... o nosso organismo... cria o hormônio... e... a carne de vaca... o leite integral... o queijo... tudo isso provoca colesterol... o colesterol provoca... é... crescimento... aumento de hormônio... você não precisa disso... o seu organismo já aprendeu a criar isso... aprendeu até de mais... então... você não pode mais brincar com gordura animal... a partir de agora... e eu vi que não é todo mundo que tem esse tipo de orientação... eu cheguei a brincar um dia... mas eu disse isso... esse pessoal trata o doente de câncer como... parece um samba do crioulo doido... ninguém sabe...

Nesta fala, podemos ver a diferença de papeis de dois médicos, onde o primeiro a atendeu de forma mais "humana", se disponibilizando em outros horários e locais diferentes do ambiente hospitalar para o tratamento, que, para quem está fragilizado parece ser ótimo, pois, se busca um "colo"; e, o segundo, ela retrata o tratamento impessoal, onde ela detecta um "erro" durante a consulta (a médica parecia não estar lhe oferecendo a atenção que ela julgava como sendo necessária naquele momento e, a médica ainda solicitou um exame que não havia a necessidade de ser realizado). Ela faz uma relação sobre o erro que foi cometido contra ela como se tivesse ocorrido com qualquer outra pessoa, que foi o caso do exame desnecessário e caro, o que parece ser uma grande conscientização da paciente do que acontece no ambiente hospitalar.

Faz referência, também, aos profissionais da radiologia como sendo muito humanos. O tratamento pelo nome, o perguntar e afirmar se ela estava bem, provavelmente fez com que ela se sentisse mais acolhida, e não apenas mais uma fazendo radioterapia. Então, em um primeiro momento, ela se refere ao tratamento da equipe da radiologia como sendo muito humano, e, num segundo momento, ela 
joga um comentário que pareceu ser genérico sobre o tratamento desses profissionais "parece um samba do crioulo doido".

Ela comenta sobre o trabalho da nutricionista como sendo de muita importância em seu tratamento, e, vê que poucas pessoas têm esse acesso.

Em meio a problemática, perguntamos se ela sentiu necessidade de procurar alguma ajuda psicológica, ou se ela teve contato com psicólogo durante o processo, pois, percebemos que ela ainda não tinha tocado neste assunto. Ela responde da seguinte maneira:

[...] e a partir do meu problema... eu comecei a fazer análise mesmo... então... me ajudou muito na época da crise... o sofrimento era muito grande... é... você já sabe o que que fala... e nada é novidade... você vai... tem tudo ali... você... senta... são duas horas e meia pegando remédio... você começa a passar mal... daí você passa mal a noite toda... e aí, depois, você não é dona de você... Então a minha analista... eu normalmente tinha sessão no dia da quimioterapia... então eu ia lá e em seguida eu ia pra quimioterapia... e me ajudava muito... me preparou assim de que... parece-me que falando com ela... eu não tentava fazer de conta que... não ia acontecer nada... eu encarava... vai ser isso, mas daqui há uma semana, o quadro já começa a melhorar... então eu ia focando o que ia ser ruim... mas esperando e já encarando "não... mas, é só mais uma semana"... e essa... já depois dessa quimio, faltam só mais duas ou mais três... então... ela me ajudava nesse sentido... de encarar...

Segundo 1, a presença do psicólogo a ajudou durante o processo. Durante as sessões terapêuticas, ela pôde trabalhar tanto a quimioterapia quanto a radioterapia, além de trabalharem juntos (ela e o psicólogo) com as reações adversas que ocorrem durante o tratamento. O que, segundo Maldonado e Canella (2003), é o psicólogo o profissional competente para trabalhar o paciente que está circunstancialmente deprimido.

Partimos, então, para a família. Perguntamos como ela via a ajuda de sua família durante todo o processo, se a família a ajudou durante o tratamento, se esteve presente, e, como ela percebia tudo isso. Então, ela responde:

Não... quando eu soube... eu avisei as pessoas da minha família... eles não moram aqui... eu tenho um filho que morava no Canadá nessa época... avisei pra ele... e... avisei pro meu filho daqui... e... a minha cunhada que eu gosto muito 
dela... ela veio pra cá... mas ela não ficou muito comigo... as pessoas não tem idéia de como é que ta a sua cabeça... elas não se preocupam com o seu lado emocional... elas estão preocupadas se você vai ser operada... então, o problema é você não morrer na mesa de operação... porque ela veio pra cá... mas, como a operação não seria naqueles dias, ela foi lá pra Sobradinho e ficou lá na casa do irmão dela... aí depois... o marido dela brigou e ela foi embora... então, quando eu fui operada, a minha irmã veio... eu disse que não precisava... já de medo do que tinha acontecido antes... aí ela disse... hum... “minha irmã... não... eu to indo....... eu disse "então venha no dia da operação... não venha antes... que daí o (nome do filho) fica comigo... vai comigo no dia da operação e você fica comigo a tarde... porque daí você... já ganha tempo porque eu já operei.”... Aí ela chegou a tarde... e eu voltei da operação... pelo que eu me lembro devia ser umas três horas da tarde... no outro dia eu sai do hospital... quando eu sai do hospital, que eu vim aqui pra casa com ela... ela me disse "então agora eu vou voltar"... aí eu disse pra ela "mas... fica mais um dia? Vai embora amanhã? Fica até sexta-feira?"... Aí ela ficou e foi embora no sábado... eu acho que eles não têm idéia de que a pessoa precisa de um suporte... sabe? Inclusive eu acho que se eu tivesse alguém... e outra coisa que também eles não avisam... eu... depois que eu terminei a quimioterapia... eu fiquei sabendo que as pessoas que fazem quimio não podem morar sozinhas... e eu morava... morei sozinha o tempo todo... então eu acho que, se eu tivesse uma pessoa a mais... ou eu tivesse uma família mais presente... o que quer que seja... eu teria ido melhor... mas... eu acho que as pessoas não estão preparadas... elas têm muito medo...

Nesta fala ela demonstra a falta que sentiu da presença de sua família neste contexto. A falta de apoio e amparo de seus familiares durante o processo foi visto por ela como um ponto negativo, pois, ela relata que se tivesse tido este apoio, teria lidado melhor em todos os contextos. Como já citado anteriormente, Ribeiro (2003) diz que tem sido comprovada a importância das relações afetivas como um fator relevante para o bem-estar de qualquer ser humano. Mas, ela sente uma necessidade de justificar essa ausência dizendo que as pessoas não estão preparadas para lidar com isso.

Dias e Durá (2002) explicam que

O diagnóstico de uma doença grave desencadeia uma crise vital na família. Exige do paciente e de sua família mudanças de papéis, buscas de estratégias para enfrentar o problema, 
uma alteração de posturas, atitudes e comportamentos, como também um longo período de adaptações a essas mudanças.

Uma outra fala interessante de nossa participante, aparece quando perguntamos "mas a cirurgia foi no meio do semestre, certo? Você chegou a trancar a faculdade?", que ela responde:

[...] mas eu toda vida fui meio neurótica... então... como eu sou aposentada... é aquela coisa de... eu tenho que estudar muito... que é a única coisa que eu faço. Então, quando eu... eu tive a doença... eu já estava terminando o semestre... eu já tinha feito prova... e eu já estava com nota muito boa... então... aí foi quando eu decidi que... cinco, pra mim, era SS. Então aí... eu já levei... quer dizer... eu só quero passar de ano... eu quero ficar com a minha turma... eu é não queria é... depois... parar de estudar... que vinha aquela coisa de que... eu... eu parei... que a doença me fez parar... que eu não dei conta... sabe? Não... eu não quis isso... o segundo semestre foi mais difícil, porque foi com a quimioterapia[...]

Sua fala parece demonstrar um medo de ficar pra traz ou, talvez, o medo de parecer diferente ou incapaz por causa da doença. Não podemos afirmar, mas, caso umas dessas afirmações seja positiva, ela não estaria fora da normalidade, pois, segundo muitos autores da área, o medo é um sentimento freqüente no paciente com câncer ou qualquer outra doença crônica.

E, fechamos a entrevista pedindo que ela fizesse uma síntese do que vinha acontecendo com ela mostrando o que ela pensava de tudo isso. Ela responde da seguinte forma:

Olha... eu... eu acho que foi uma oportunidade... sabe? De... de... de crescimento... de... de valorização... é... depois de tudo... eu tenho me sentido muito insegura ainda... estou mais aberta a receber coisas... tenho mais entendimento pra... pra entender que as pessoas não podem dar aquilo que você acha que deveria ser dado... parece que eu tenho mais discernimento com as coisas... com meus filhos eu to mais... mais afetiva... parece que meu lado afetivo... eu acho que ele aflorou mais... parece que eu to mais aberta... eu acho que é um tranco tão grande... é uma... uma pancada tão forte... que a partir daí, você... melhora com você... e automaticamente com outras pessoas... ou você não levanta mais... eu vejo exatamente assim... e eu acho que... que você não se prepara pra isso... você fala "a partir de hoje vai ser 
diferente"... não... não... engraçado... você se ver assim... sabe? Você... pô... como eu to diferente agora... como eu me vejo diferente agora... como eu to reagindo diferente... então... parece que as coisas mudam... as coisas acontecem e eu acho que elas mudam...

A fala de nossa participante durante toda a entrevista, esteve em vários focos, passando pelo medo, pela angústia, pela decepção, porém, sempre com reflexão positiva sobre a realidade. Uma paciente que, em um ano, passou do diagnóstico para uma provável cura de seu câncer, hoje, já vê seu presente de uma forma diferente; mesmo que possa existir o fator "recidivo", ela demonstra um grande avanço quanto ao enfrentamento e aceitação de seu diagnóstico. A falta do amparo de sua família, é realmente um fator relevante para um avanço positivo do prognóstico, que, neste caso, pode estar influenciando uma demora neste desenrolar.

A outra participante será chamada de 2, é uma mulher de 59 (cinqüenta e nove) anos; e, seu câncer de mama foi diagnosticado em julho de 2006; e, ela retrata da seguinte maneira:

Eu recebi a notícia no dia 25 de julho de 2006, fazendo uma mamografia depois de 3 anos... é... sem fazer a mamografia. Então, essa doutora, que é a radiologista, ela fez a comparação... e... como ela tem um aparelho preciso, digital, de alta recepção... eu fui até uma das primeiras a usar este aparelho... ela aí percebeu que eu estava com dois nódulos e que com certeza seriam cancerígenos.

A partir do relato inicial de 2, foi perguntado se ela não havia sentido nenhuma alteração em seu seio e se já vinha tendo sensações características do câncer. Ela respondeu o seguinte:

Não... não percebi... Eu só sentia cansaço. Mas hoje em dia todo mundo vive cansado... então a gente... é complicado né... uma coisa que eu não posso colocar como referencial. Mas não sentia...

É uma relação muito interessante que ela faz sobre o cansaço: como colocar o cansaço como referencial se todo mundo vive cansado? Por mais que o sintoma "cansaço" fosse referente ao câncer, que já estava em desenvolvimento, não houve uma preocupação quanto a isso, por ser um problema comum nos dias de hoje. 
Perguntou-se se ela tinha conhecimento sobre o câncer e o que ela sabia antes do diagnóstico, e ela respondeu:

Tinha porque eu trabalho no Tribunal Regional do Trabalho [...]. Então eu sempre tive assim essa... noção, porque lá eles sempre fazem a semana da saúde levando todo tipo de informação né... de todas as naturezas e formas pra que a gente possa ganhar uma cultura médica... e... mesmo assim, eu fiquei 3 anos sem fazer a mamografia. Aquela história: vou hoje... vou amanhã... vou depois... É... o que eu sabia... assim... né... eu, quando entrei na menopausa... é... há uma diminuição dos hormônios né... e a mulher... ela fica mais vulnerável a ter... essa diminuição dos hormônios né... mas... é quando ela tem assim... uma maior incidência né... mas... é... a fase em que há um... todo o organismo... ele vai entrar numa fase como se fosse um... estado decrescente... então, essa fase aí é que é uma fase mais... sensível... daí... a recomendação de todo ano, a gente fazer a mamografia. Apesar de eu não ter tido filho... e apesar de também terem... é... assim... assuntos e comentários a respeito de que... quem não tem filho, tem também uma probabilidade de ter câncer de mama... Mas, eu conversando com o meu mastologista que me atendeu e tudo... ele falou que isso não é real... e o grande problema é o seguinte... que quando a gente entra na menopausa, a gente tem uma série de... de comportamentos inadequados... ou seja, a gente tem tristeza... a gente tem suor... a gente fica irritadiço... a gente tem dor em tudo o que é lugar... e... a gente... normalmente... se recorre a reposição hormonal... e... essa reposição... para alguns cai muito bem... para outros, não... e no meu caso, eu quis insistir porque, eu estava com problema de pressão... eu tive picos hipertensivos... porque eu... acumulava muito líquido... então eu quis fazer essa coisa pra ter um... um conforto... né? Porque a pressão alta realmente não é uma coisa muito agradável... e fui fazer exercícios e tal... mas eu... é... tive uma... dosagem muito pequena e tive cuidado também de... fazer a aplicação desse hormônio... de forma que ele não fosse diretamente pro fígado... ou seja, gel e os adesivos... mas isso... não me deu... eu não tive compatibilidade com nenhum... eu tentei... depois, realmente eu resolvi... desisti... porque eu continuava com a minha pressão alta... então... eu... identifiquei o exercício... e... procurei realmente cuidar da minha pressão sem ficar ligado só a questão do hormônio... então eu achei que isso é que foi um ponto... é... que ainda... a minha situação não ficou pior... mas eu acredito que esse hormônio... com certeza... deve ter interferido porque... na biopsia... nessa avaliação... esse meu tumor... ele 
é alimentado pelos hormônios... tanto que eu terminei agora a radioterapia e vou continuar fazendo um procedimento que é tomar um remédio para a queda de hormônio durante cinco anos... porque eu ainda tenho uma probabilidade de acontecer uma... recidiva... entendeu? Porque um tumor foi de uma natureza e o outro foi o que eles chamam de infiltrante... que realmente pegou um linfonódulo, tanto que eu um esvaziamento axilar... porque... precisava fazer a biopsia e eu não queria fazer duas, três, quatro, cirurgias... eu fiz uma só... já pegando todas as oportunidades pra que eu tivesse uma recuperação melhor e pudesse... enfim... fazer a quimioterapia e a radioterapia já no sentido de... solucionar mais rápido essa situação né... quanto mais rápido você resolve... mais rápido você detecta... e... então... e a recuperação também... eu passei doze horas de cirurgia... então foi... muito tempo né... é... mais graças a Deus eu passei muito bem né... a minha recuperação foi boa... e terminei a radioterapia por coincidência, ontem... tem aqui umas lesõesinhas que são naturais também... porque é uma queima do tecido né... mas... é... o que eu sabia do câncer de mama... é que... é essa parte hormonal flutuante na mulher que leva a essa tendência... isso, se a gente falar... fisicamente... é... cientificamente... é... enfim... dentro dessa linha... mas... eu percebo também que... tem um outro fator que... do câncer que... é... a gente não pode menosprezar... eu acredito que é a natureza da pessoa... porque, assim com tem gente que recebe hormônio e não tem problema... fica muito bem... né... tem outros que não ficam... então eu acho que isso é muito ligado à natureza da pessoa... então... por exemplo... eu tenho um componente do hormônio... né... que é desfavorável... mas... eu sou também uma pessoa emotiva... então... que isso também possa ser desfavorável... porque se eu não tiver esse... vamos dizer... esse... essa emoção no controle, ela conseqüentemente... ela conseqüentemente vai ser desfavorável pra mim... então eu acredito que isso possa ter contribuído... né... eu não posso afirmar pra você... mais fazendo assim... uma retrospectiva de tudo... eu diria isso né... e hoje em dia você vive emoções fortes... não tem jeito né... eu... ligo muito a esse fato porque... eu tenho uma sobrinha que mora nos Estados Unidos... meu irmão caçula mora lá há muitos anos... e ela foi... já está na Universidade... e eu recebi a notícia de que ela tinha sido internada... e que ela estava realmente muito mal... e eu fiquei assim... mais como? Mal?? Não sei... parecia que era um surto psicótico... e eu falei... gente... e sem ter notícia... aí aquilo... e eu fiquei preocupada por ela e pelo meu irmão... ai depois ele ligou pra mim... e ficou sabendo que na faculdade... ela foi lá 
numa festa e tal... e que uma das colegas falou que fizeram o boa noite Cinderela... e que isso nos Estados Unidos é até comum... é comum aqui com a gente... né... balinhas e etc e tal... mas pra mim... eu acho que isso teve... assim... uma repercussão... é... primeiro que você ta longe né... e segundo que você sente uma violência... assim... muito grande né...

Mesmo vivendo em um contexto médico, recebendo informações importantes sobre saúde, se viu adiando várias vezes sua mamografia. Ela também demonstra ter muito conhecimento sobre o seu tipo de câncer, e, o quanto teria sido importante ter detectado antes. Vê-se como uma pessoa de sorte por ter dado tudo certo.

Carvalho (2003) diz que a presença do estresse pode facilitar o desenvolvimento do câncer por meio do rebaixamento do sistema imunológico, mas não existem evidências de que o paciente de câncer tenha sofrido mais situações de estresse do que pessoas não-doentes.

O fato ocorrido com sua sobrinha aparece durante o assunto como se fosse uma justificativa pelo que estava acontecendo. Sua preocupação e desconforto em ter que esperar notícias e não poder ajudar devido à distância, pode ter contribuído no processo, porém, é algo que não podemos usar como justificativa.

Porém, perguntamos há quanto tempo isso aconteceu a fim de visualizar se houve uma coincidência de datas. Ela relata o seguinte:

A... isso deve ter uns três anos [...] logo depois desencadeou... eu tenho pra mim que esse foi um dos fatores que pode ter contribuído... devido a minha sensibilidade né... é... isso eu acho que foi um fator que contribuiu... fazendo... isso que eu digo... uma análise do que é que poderia ser... porque é como eu digo... cansaço... estresse... emoção... todo mundo tem... uns é mais... outros menos... eu acho que pra mim foi... como a minha característica é mais emocional... eu creio que pra mim isso foi uma coisa mais... é... assim... foi uma coisa que me tocou... realmente... eu me senti totalmente impotente... de uma situação já consumada que a gente não tinha como resolver... ela ficou dez dias internada... hoje em dia ela ta bem... ta com perspectiva de vida no Brasil... e eu quero estar com ela porque até pra poder a gente ficar bem né... se sentir bem... estar bem..." 
Nesta fala há uma tentativa de justificar a vinda da doença com o ocorrido com a sobrinha. Segundo Carvalho (2003) "sentimentos de impotência, vulnerabilidade e fragilidade ao lado de perda da autonomia são experimentados intensamente".

Como ela fez a relação, perguntamos há quanto tempo ela deveria estar com o câncer em desenvolvimento, e ela responde o seguinte:
Ah... Falou. Ele disse que deveria estar... que eu já deveria estar com isso há uns dois anos... dois anos e pouco... Quase três anos... eu fiz a última mamografia... estava bem... e... logo a seguir eu acredito que deva ter desencadeado esse processo... foi mais ou menos... a... depois da notícia... e tudo isso né... então eu acho que foi uma coisa que deve ter contribuído né...

Perguntamos se havia algum outro fato que ela considerasse marcante durante os últimos cinco anos, a fim de verificar se existia mais algum fator que ela considerasse como contribuinte ao aparecimento do câncer.

Não... não... nenhum fato que eu achei... assim... marcante... lógico que era... trabalho... e... estudo né... então a minha vida... apesar de não ter filho... eu não tenho uma vida parada... eu tenho uma vida ativa né... sou professora de kebana né... de arte mora (1...) mas eu também acho que eu não tinha uma vida pra se dizer que era um estresse [...] eu acho que era legal... e... o estresse que a gente tem é normal... que nem você tem... que a gente ta tendo notícia aí de coisas que a gente não pode nem dar muito ouvido porque a vida continua... e essas coisas também terão que acontecer e a vida tem que continuar... faz parte do ciclo da vida né... até da nossa evolução. Então... é... eu acho que... eu não tive assim... o único fato que eu achei marcante foi... que realmente me sensibilizou muito... realmente foi esse... que... foram duas situações... a da sobrinha e a do meu irmão... então... uma coisa que... a gente... não tem como... é uma dose dupla... vamos dizer assim né... eu tive muita preocupação com ela mas também tive com o meu irmão né... é um pai vendo uma filha sofrer... é um ambiente estranho... outra cidade... sem a notícia... eles são pegos assim... vamos dizer... de surpresa né... o que eu fiquei impressionada é que isso é comum nos Estados Unidos... a gente fica alarmado né..."

Chiattone (1998) nos diz que o paciente com câncer adoece como um todo, pois, junto com a doença, estão a consciência e os sentimentos frente à enfermi- 
dade, com as repercussões próprias e pessoais na maneira de viver, de adaptar-se ao estresse vital e delinear seu próprio destino. Com isso, sentimos a necessidade de perguntar qual o motivo de não ter tido filhos, pois, esse fator também pode ter sido relevante para o aparecimento do câncer, e ela respondeu:

Não... eu não tive porque eu tenho a chamada tireoidite de rachimoto... que também, eu tive conhecimento agora... isso é tudo mais recente... não é da minha fase de jovem... é como se o meu organismo rejeitasse a minha tireóide... então eu tenho muita disfunção hormonal... e isso... uma das coisas que provoca é a infertilidade... e... não, também, na minha época... não tinha... esses... exames avançados... fertilização in victro... enfim... toda essa coisa que eu pudesse... ter lançado mão... então... como foi... quando eu comecei a entrar nessa área pra ver fertilidade, eu percebi que... na minha época... eram coisas muito dolorosas... muito... e eu cheguei a conclusão de que aquilo não valia a pena... que eu tinha que seguir o curso natural... não veio filho... não é pra ter filho... e... e toquei minha vida... é... com outras coisas... outros focos... né...

Preferimos não rodear muito neste assunto com o intuito de não trazer maiores constrangimentos, angústias e/ou aflições sobre o tema. O cuidado com a sobrinha parece ser em virtude de não ter tido filhos. Porém, não é algo que podemos justificar.

Perguntamos então, se o médico havia feito alguma relação de seu câncer com sua disfunção hormonal, e ela diz o seguinte:

Não... porque tem gente que tem isso e não tem câncer... mas... é um propensão... Então, dentro... vamos dizer assim... dentro do que é falado... eu não tive filho... eu tenho a tireoidite de rachimoto... e tive... um estresse... traumático... vamos dizer... e isso poderia ter ajudado na minha... que eclodisse o câncer de mama...

Essa frase parece bem típica de uma justificativa para o "ter câncer". Ela mesma faz toda a relação histórica. Hughes (apud Carvalho, 2003), diz que o câncer "provavelmente não tem uma única causa, mas uma etiologia multifatorial, isto é, vários fatores precisam operar juntos na mesma pessoa para produzir a doença”. As teorias que se referem às contribuições psicológicas para o crescimento do câncer devem ser analisadas seriamente. 
O recebimento do diagnóstico é relatado por ela da seguinte maneira:

Bom... eu quando recebi o diagnóstico... eu, inicialmente, achei que não seria câncer... então... fui fazer o procedimento logo de imediato... mas eu vi a ansiedade das médicas lá do... do Tribunal... no sentido de agilizar né... então eu... percebi que tinha algo... elas querendo me tranqüilizar, mas, eu vi uma pressa muito grande... mas também não liguei ao fato, porque eu acho que a gente tem que correr... realmente, quanto mais rápido, melhor... e aí, fui fazer a pulsão, e tal... numa sexta-feira... e, na segunda eu recebi o resultado... e aí... quando eu vi o resultado... que eu sai do laboratório... aí eu vi... é... é... câncer ductal infiltrante... quando eu vi infiltrante... aí eu vi que a coisa era séria... aí você tem aquele choque... mas, assim mesmo, eu não chorei... não tive nenhuma reação... fui pra casa... aí quando a minha chefe ligou... de noite pra mim... eu tinha ido... no final da tarde buscar... que era quando ficaria pronto... que ela ligou pra falar comigo e... aí é que eu... é... assim... falei... eu disse... “puxa! Eu acho que a situação é muito séria....... ela falou "não... não é sério... é... você tem que pensar em todas as possibilidades que você tem....... então eu fiz aquele... aquele pensamento né... ou eu ficaria numa linha em que eu ia me envolver com a doença... ou eu... ficariam numa linha que eu acho que seria o envolvimento com a vida... e... nesse ponto... eu acho que eu sou privilegiada... porque antes de acontecer tudo isso comigo, eu fui fazer psicologia... justamente, tentando fazer um trabalho... pra minha... quando eu me aposentar... já na minha preparação de aposentadoria... é... eu... fazer um trabalho... é... ligado... com a Flor... que é um trabalho que não tem né... a renda... ligado, justamente a essa arte né... de ekebana... e que é uma coisa assim, muito interessante... eu tenho muita experiência nisso... então eu quis formalizar isso, pra fazer um trabalho, realmente... de... credibilidade... de... de... de tudo... enfim... então eu entrei nesse caminho... já vinha por esse caminho... e eu aí pensei... eu digo... não... não posso parar a faculdade agora... porque se não eu vou me atrasar... então eu... to correndo contra o tempo... da idade... e, com isso... eu acho que me ajudou... porque eu me envolvi... no meu projeto de vida... e não numa situação que... que é fazer a morte... que isso também foi uma coisa que a ekebana me ensinou... que na vida, você não pode ser só... mulher... casou... trabalho... filho... não... você tem que ter uma diversificação... pra que você possa ampliar você como pessoa... né? Então você tem outros leques... que possam preencher você... que vão dar suporte, justamente nesses momentos... então eu acho que isso eu já vinha num processo... e isso me ajudou. Então 
eu tive logo a fase do choque... mas... ao mesmo tempo... eu... a... eu estava tão envolvida nesse projeto que eu... me deu forças pra eu... é... assim... ficar no foco, realmente, da vida... outra coisa que eu vi também... o privilégio de eu ta podendo... me cuidar... porque você sabe que é uma coisa cara... né.. e... eu ter tido condição de resolver... de... financeiramente... é... de eu ter oportunidade de ter acesso, inclusive, a radioterapia... porque aqui em Brasília só têm dois aparelhos... é muito difícil... eu consegui... tem gente na fila de espera... é um negócio muito... complicado... muito... drástico... até... se a gente for falar em termos de... de... disso né... é... é uma linha que, realmente você ver... aí você ver... as... as coisas que eu fui privilegiada... então... isso aí... também... cresceu a minha... visão... com relação a coisa do otimismo e não do pessimismo... porque eu acho que todas as condições, tão sendo dadas pra mim... pra que, realmente, essa vida seja estendida... então eu tenho que... acho que ir nesse caminho... se eu for pelo outro lado... eu não vou ser... vamos dizer... não vou estar valorizando aquilo que eu estou recebendo... entendeu? Então eu vejo mais ou menos por isso... de eu ta podendo me cuidar... de eu ter... tido condições... né...

Segundo Amaral (2003), quando se recebe o diagnóstico de uma doença como o câncer sente-se assustado, desamparado e impotente, assim como ela mesma relata. Como objeto de enfrentamento, ela fez uso da Ekebana, o que parece ter a ajudado relaxar durante o processo. A Ekebana é uma técnica oriental de arranjos florais feitos com flores naturais. Um dos fundamentos desta técnica é colocar para fora o que está oculto no interior de cada um de nós.

Ela valoriza o fato de poder ter tido condições de bancar seu tratamento, tendo em vista de que não é num valor tão acessível, ou seja, muitos não conseguem terminar, ou até mesmo fazer o tratamento devido ao seu alto custo.

Perguntamos, então, se ela já havia tido algum contato com pessoas com câncer, e ela respondeu:

Já... eu pratico Johrei... não sei se você conhece... e... na prática do Johrei... eu ministrei e acompanhei muito as pessoas com câncer... inclusive uma amiga, muito chegada minha... que... ela teve... re... assim... rejeição pra se cuidar... porque... entrou realmente numa situação... vamos dizer... de... de exauri a questão dela de vida... e ela aí... se deixou levar... e quando foi... realmente fazer o tratamento... a coisa já tinha uma outra proporção... então... eu acompanhei 
ela até ela falecer... então eu tive muito contato... né... essa área... e inclusive com colegas do tribunal né... teve uma, também, que não foi o de mama... essa, específica, foi de mama... as três que eu acompanhei... e essa outra foi... no pulmão... fumava muito e um dia ligou de casa pra... eu trabalho dentro da área médica... ela não estava se sentindo bem... e aí eu providenciei uma ambulância pro hospital... e aí quando ela tava lá com o médico do tribunal... já se percebeu alguma coisa aí... daí ela já não voltou mais pra casa... e... veio a falecer... foi uma coisa muito rápida... foi uma coisa muito rápida..."

Assim como S.N.S, I.G.C.S também faz referências à casos de câncer que não tiveram bons resultados. Talvez, isso se deva ao fato de estar vivenciando um momento específico da doença, onde, o medo ainda é prevalecido. Porém, é um fator que não podemos justificar muito. Sua fala foi rápida e pontual, passando-se rapidamente para outros assuntos sem deixar muitos espaços para perguntas relativas. Muitos autores diriam ser uma fuga da realidade ou medo do pior, mas, nada que podemos dar certeza nesta fala.

Ela cita em sua fala a prática do Johrei, uma técnica utilizada pelo movimento religioso japonês, que significa purificar o espírito ou batismo pelo fogo, ou seja, purificar o homem pela energia do fogo. Segundo os adeptos, na condição de canal da "luz divina", o messiânico qualifica-se para ministrar Johrei em qualquer lugar onde se encontre, transmitindo a luz de Deus para o seu semelhante e, também, para si próprio através dou auto-Johrei. Esta técnica é baseada nas leis da natureza e serve para ampliar a força de recuperação natural do homem, eliminar suas máculas espirituais e restabelecer na sua vida a harmonia original, estabelecendo com Deus um especial estado de união. Esta prática religiosa parece ter contribuído bastante para uma melhora.

Em seguida, perguntamos a ela se, após o diagnóstico, acabou voltando sua percepção para as pessoas que tivessem câncer, e se conheceu mais alguém com o mesmo diagnóstico. Ela responde que:

Não... eu...é claro que... você entra pra fazer a quimioterapia... você... vai falar com aquela turminha toda... dentro dessa... dessa estatística... vamos dizer né... dentro desse quadro... e... mais... assim não... agora, o que eu achei interessante foi que a minha família... é... mostrava... "olha, saiu uma reportagem!", "olha, saiu uma reportagem!", “olha, saiu..., 
nem eu mesma tive... assim... isso não veio bater nas minhas mãos... mas... eles mostravam que... "olha aqui... ta tudo bem... e tal"... inclusive... até muito interessante... essa semana mesmo, na segunda-feira, uma colega minha de... de... turma... ela levou uma revista... acho que é do correio brasiliense... que fala a história de duas pessoas que tiveram câncer de mama... acho que foi essa semana passada né? E ela veio... e eu até nem tinha lido... por isso que eu digo pra você... é interessante.. e essa semana mesmo... também... ontem eu até conversei quando eu fui fazer a entrevista... que eu... ouvindo... a... o noticiário do Bom Dia Brasil... é... foi feito uma entrevista... é... um... fotógrafo... ele utilizou de... justamente as mulheres... que tiraram os seios... enfim... que tiveram todos... todo o processo né... do... do... do câncer... tirando fotografia... e, tem montado, assim, na cidade, uma exposição a respeito disso. Eu ainda não fui ver... Não sei... não peguei qual é o local... mas... eu to querendo ver se nesse fim de semana... se ainda tiver... eu vou dar uma olhada... que eu acho que é uma coisa interessante, até pela própria entrevista do fotógrafo né... ele foi muito... assim... ele... disse que... a.... ele aprendeu... ele ficou surpreso... porque... ele achou que ia ficar, assim, um pouco inibido, e que, elas é que tiraram a inibição dele. Então... eu mesma... assim... de ter contato, não... né... mas... as coisas vieram bater na minha mão por efeito..."

Percebemos em sua fala que ela se sentiu bem acolhida pela família e amigos no que diz respeito a informações sobre o câncer. Como ela mesma diz, não precisou procurar muito, pois as pessoas que estavam ao seu redor lhe traziam o que viam. Coelho (2001) reporta que "pode-se observar famílias que encontram seu equilíbrio em torno dos cuidados e atenção oferecidos ao membro enfermo".

Porém, ela fugiu do contexto da pergunta; apenas se limitou a responder que conheceu a turminha que fazia a quimioterapia com ela, partindo em seguida para informações trazidas. Então, perguntamos como foi a cirurgia, e ela respondeu da seguinte maneira:

A cirurgia... foram doze horas de cirurgia... e... né... e que ele... fez o esvaziamento axilar... tirou o dois tumores... e... ele fez preenchimento com a própria mama... né... então... é uma coisa muito dolorida né... porque eu fui muito mexida... mas... eu acho que isso também... eu tava tão feliz de ter me operado... de... ter dado tudo certo... que eu não passei mal nem nada... que eu... esses outros incômodos... eu... eu nem... nem me dei conta... fazia parte né... nem me 
dei conta... inclusive o pessoal da faculdade veio me visitar... "Isabel, você perdeu os peitos e ganhou um rabo!"... porque eu tava com o dreno né... e aí me tiravam pra dançar... e eu com o dreno... fizeram a maior farra aqui comigo quando vieram me visitar... então eu falei "ó gente... to aqui numa boa...... eu tava feliz porque tinha dado tudo certo na cirurgia... que era uma etapa que poderia dar problema... né... que é uma cirurgia longa... mas... graças a Deus deu tudo certo...”

Sua fala parece alegre ao falar da pós-cirurgia. Teve os amigos presentes durante esse processo, o que deve ter contribuído para uma melhora rápida, ou, pelo menos, menos dolorida.

Sobre o procedimento cirúrgico, respondeu apenas que foi longo e dolorido, mas, que estava feliz por ter dado tudo certo. Suas expectativas parecem ter sido alcançadas de forma positiva.

Perguntamos em seguida, como foi o processo de quimioterapia, e ela responde da seguinte maneira:

Olha... o processo de quimioterapia, realmente (risos)... o que a gente pode dizer sobre o processo... é... que a gente vai no porão... é uma coisa muito... sofrida... porque é aquele mal estar... é muito grande... a... o processo de você ta ali... é lógico que eles te explicam... dão cartilhinhas pra gente e tudo e tal... mas você percebe alguns... movimentos né... então, por exemplo, tinha uma etapa lá... da quimioterapia... que o enfermeiro ficava perto... e eu me lembro que ele olhava... e olhava... e olhava... e isso no início a gente nem percebe tanto... mas depois, eu fiquei sabendo que é o momento mais... é... complicado da quimioterapia... porque não pode sair da veia... não pode... é... comer tecido... você pode, realmente, passar muito mal... e... enfim... é um momento... são duas horas... duas horas e pouco... que você passa ali... é realmente... como eu te disse... você vai no porão... você não tem nada que te distraia... você pode ta na frente da televisão... você pode ta conversando de moda... essas coisas... e tal... mais é um momento único... de um... de você com você... não tem jeito... é uma realidade que você não tem como fugir... então é uma coisa muito forte... eu acho a quimioterapia, realmente uma coisa muito forte... que ela dá um mal estar muito forte... eu senti que era um desafio... então eu ia... e... quando eu saia de lá... eu ainda... ainda... no primeiro instante... você fica bem... fica até... acabou... menos um... menos um né... você tem a história do menos 


\begin{abstract}
um... ai... depois que você começa a ficar ruim... é o cheiro... é o vômito... é o... aí é o mal estar... é todo o processo... daí você fica prostrado mesmo... e aí você sente tudo né... e... e... e fica detonado... (risos) literalmente detonado... então... mais eu achava assim... e... essa sensação... ela fica assim... mais ou menos uma semana... você tem um espaço de vinte um dias de um pra outro... e eu já começava a me sentir bem... e... automaticamente... é como eu disse pra você... estudar... eu já tinha que... então... eu não valorizava muito aquilo não... e as pessoas chegavam pra mim "Isabel, você está tão bem!" "Você não ta nem amarelada nem nada”... e eu nem sei... eu me achava um amarelão... mais... então eu falei "gente, então eu to ótima... ai que bom!"... e vivia com aquele espírito também pra lá... assim... nossa... eu vou... se tiver alguém lá muito mal... muito... elas são fantásticas né... literalmente fantásticas... aí eu falei se hoje tiver alguém lá precisando, daí eu vou dar uma força... então eu ia também com esse espírito..."
\end{abstract}

Pôde-se perceber que o processo de quimioterapia não era uma coisa "gostosa" de se fazer. Porém ela demonstra não ter valorizado os contras deste processo. O fato de seus conhecidos próximos a dizerem que ela estava com um aspecto bom, a deixava mais positiva quanto ao andamento do processo; inclusive para se disponibilizar para ajudar outras pessoas que necessitassem de sua ajuda.

Perguntamos se ela chegou a ajudar alguém durante este processo e ela se limita a responder "Cheguei... muitas pessoas..."; então, perguntamos em seguida se precisou de ajuda em algum momento.

É... também... Meu marido, inclusive... no último dia... foi me ministrar johrei... porque foi o dia que eu fiquei mais... porque eu tinha passado muito mal... ainda não estava muito bem... mas ela disse "não, você pode fazer que seu exame está bom" e... quando você tem uma... queda dos leucócitos... né... que você apresenta leucotemia... que é essa baixa dos glóbulos brancos... você tem que tomar uma injeção pra reativar... e essa injeção é na barriga e você... dói o corpo todo... você fica com dor nas cadeiras... é como se você tivesse andado à cavalo... porque as ancas... a parte interna... né... da... perna... é dor... você fica direto no tilenol porque se não você não dá conta... e eu... tava ainda preocupada... porque eu tava ainda... porque ela falou "não... pode isso..." daí eu falei "não... eu tenho que confiar"... aí eu fui... e fiquei emocionada também porque eu preparei um mini arranjo pra todo mundo como gratidão 
né... é... por ter convivido ali... com eles aquele tempo né... então eu fiz seis sessões né... é mais ou menos seis meses... porque vinte e um dias né... e... então aquele convívio... e vai lá... e consulta... e se prepara pra fazer... porque a gente faz exames antes de fazer a quimioterapia... então eu tive todo esse processo... assim... de convivência né... então eu quis fazer... agradecer... realmente... porque, também, o trabalho deles não; e fácil... né... eles não tem um... uma coisa assim... que você possa dizer que é prazerosa... estão ali... sabendo que vai iniciar o dia vendo aquele contexto q vão terminar o dia vendo aquele contexto... vendo sempre aquele quadro e tal... então... uns são mais risonhos... mais alegres... outros são mais depressivos... enfim... é... um... universo riquíssimo ali... de pessoas... de papo... e tal... então pra mim, a quimioterapia foi o momento mais difícil... então... nesse último dia eu fiquei muito emocionada porque eu tava terminando... e eu já estava com problemas nas minhas veias porque a quimioterapia vai secando... então eu tava muito receosa porque eu ainda fazia os exames de sangue... quer dizer... você ainda tinha que furar mais veia né... e... usava sempre o mesmo braço porque eu não posso mais utilizar esse braço por causa do esvaziamento axilar (mostrou o braço esquerdo)... ele fica com a imunidade comprometida... então... eu não tiro cutícula... não faço nada disso... entendeu? Eu tenho que ter muito cuidado... pra não cortar... nem coisa... nem nada... porque ele é mais vulnerável a... a dar infecção... né... e então... eu... eu... tava assim... preocupada... com o negócio de... "será que vão conseguir pegar minha veia?"... e tal... se não der vai fazer um cateter... que é um condicionamento aqui né... e tal... então eu acho que isso tudo... emoção, término... aquela coisa toda, e tal... então eu comecei a chorar... e tal... aí o enfermeiro "ah... ela ta com saudade de você..." dizia pro meu marido né... aí meu marido veio imediatamente... começou a ministrar johrei em mim e tal... e... depois foi passando aquela coisa... e tal... conseguiu pegar a veia... deu tudo certinho... tudo beleza... aí você fica uma sensação... é... é muito engraçado... de... de dever cumprido... sabe... você... parece que você... é... você tem a opção de não fazer né... porque tem muita gente que ta lá e que quer desistir... que não volta... entendeu? Mas eu cumpri essa... etapa... então... 'um dever cumprido... pra mim... entendeu? Eu acho que... é como se... vem um desafio e você ta... é... correndo atrás desse desafio... como se fosse uma gincana né... você tem que cumprir aquelas etapas... pra poder você ter êxito né... trabalhar pelo êxito né... 
Nesta fala, I.G.C.S traz seu esposo como grande ajudante e companheiro durante o processo de quimioterapia. Ribeiro (2003) nos diz que "a importância das relações afetivas tem sido amplamente comprovada como um fator relevante para o bem-estar de qualquer ser humano".

Perguntamos, então, sobre a radioterapia, a qual acabou um dia antes de nossa entrevista:

A radioterapia... a última sessão foi ontem... então... a radioterapia... já foi mais leve... mas... também... eu fui com uma expectativa muito grande... que seria muito fácil... que a quimioterapia é muito ruim... né... então eu já fui assim... muito fácil... sabendo que... iria... queimar toda a minha região do seio... que poderia dar bolha, como deu... pequenininha, mais deu (mostrou a região em que foi feita a radioterapia)... e... mais ou menos... mais depois volta ao normal... mas esse momento é complicadíssimo... você vê que eu to com um adesivo e não posso tirar porque aqui tem uma ferida... isso pinica... dói... arde... fica uma coisa terrível... mas esse aí não é o problema porque isso não dá logo no início não... mas você sente um cansaço... e é um cansaço assim... estranho... porque parece que você vai perdendo as forças... parece que você vai perdendo as forças... sabe... então, esse cansaço é que é uma coisa muito chata... e no meio disso, eu tive uma infecção urinária... eu tive que me internar uma semana... o que foi uma coisa muito difícil pra mim... porque no dia de páscoa eu comecei a passar mal... eu comecei a passar mal na sexta-feira... agora... no domingo de páscoa... eu tava mal... mal... eu tive que ir correndo pro hospital... cheguei lá já quase... quase tendo um troço... e eu não sabia o que que era... aí ela falou "você tem que internar"... e eles vinham cada dia me embromando “não... porque amanhã de manhã você faz os exames, se tiver legal...... mas... mentira... eles foram me embromando... porque eu ter que ficar realmente uma semana... no soro e no antibiótico... porque... você sabe que a gente fica com a imunidade muito baixa... e rim é um... é um filtro do nosso organismo... tem que ficar perfeito... e a minha foi aquela pielomestrite né... uma... uma infecção de urina... numa taxa mais alta... que também é mais difícil... porque quando você tem a baixa, normalmente dá cistite, e tal... então você já... detecta mais rápido... já tem o incomodo mais rápido... a minha não... eu tenho a sensação que eu não sabia se era estomago... se era dor muscular... se era coisa... não... mais na época eu realmente vinha dando um tilte... é... forte... e... não tava legal... aí eu sai disso... depois eu 
peguei uma gripe muito forte que eu ainda to com um restinho de tosse até hoje... e ia pra lá... e lá realmente é muito frio por causa do aparelho né... o ar condicionado em alto grau... e você bate queixo lá... e você ainda tem que expor sua mama pra poder bater o radio... então, quer dizer... você fica vulnerável aquele... aquela friagem... né... mais eu consegui... graças a Deus... e não foi... eu tive um princípio de sinusite... mas não chegou a ser infecciosa... mas deu pra debelar... então foi... foi melhor que a... a quimioterapia... eu que criei uma expectativa diferente...”

Bergamasco e Angelo (2001), retratam que pesquisas realizadas com pacientes diagnosticadas com câncer de mama demonstram que tanto o diagnóstico quanto o tratamento e suas seqüelas são muito estressantes para a mulher. Ela parece ter enfrentado de forma positiva a radioterapia, mesmo relatando vários pontos negativos desta etapa do tratamento, e, mesmo tendo adoecido no decorrer deste processo.

Perguntou-se se o fato de ter que expor a mama era constrangedor e ela relatou:

Não... nem... Quase todo dia eu levei duas horas, duas horas e meia a quatro horas pra... aguardando pra entrar lá na máquina pra pode fazer a... a radiação... mas... as pessoas...é porque entra um por um... não fica todo mundo junto né... a radiação é perigosíssima... inclusive os próprios técnicos saem da sala né... você fica ali sozinha... é outro momento, também, que você tem que fazer a sua vivencia sozinha... você não pode dividir com ninguém... eu fiquei ontem muito emocionada... também foi uma outra etapa que eu consegui vencer... vencer né... e... assim... a... vivenciei coisas ali muito interessantes... eu fiz amizades, porém olhei as coisas da psicologia... a psicóloga de lá veio conversar comigo... e... foi uma troca... assim... muito interessante... né... porque ela também quis saber do trabalho da ekebana né... então... são coisas assim... as pessoas... uma troca de experiências... isso aí... muito interessante... ela inclusive quis receber johrei... foi muito legal... e... enfim... foi assim... é bom porque você tem contato com as pessoas... as vezes você ver uma situação difícil daí você diz "puxa! To legal! Graças a Deus"... né... aí você vai... né... é... assim... sempre percebendo que você está bem... que você está dentro daquele contexto todo ali... eu chegava sozinha... eu saia sozinha... né... não deixei de comer... não tinha aquele cansaço... aquela coisa estranha né... que você ver que seu corpo é agredido por algo né... você não fica $100 \%$ mas... me sai bem... graças a Deus... 
Nesta fala, I.G.C.S. relata que no momento da radiação não foi constrangedor o te que mostrar a mama; porém, ela diz que é mais um momento que se tem que ficar sozinha. $\mathrm{O}$ não poder dividir aquele momento, parece não ter sido bom, mas, ela diz que foi mais uma etapa em que ela conseguiu êxito.

Perguntamos o que ela acha que mudou em sua vida após o diagnóstico, e, sua resposta é bem interessante:

A... eu... eu to, hoje em dia, olhando pra Isabel... eu antes não olhava muito pra mim né... acordava e vamo... vamo a luta... pro trabalho... vamo estudar... vamo... vamo... agora não... A... eu vou curtir tudo o que eu faço... to dizendo mais não... to botando limite... em muitas coisas... e to... acho que valorizando muito mais... é... o que eu to fazendo... eu já tinha feito uma escolha... e hoje em dia eu vejo que essa escolha foi realmente fantástica em minha vida... por isso que eu digo que eu sou privilegiada... porque eu já estava num caminho que só veio fortalecer mesmo... e que esse caminho também... vai me dar oportunidade justamente nisso... deu... deu... deu trabalhar... deu... deu... é... estar integrada... porque... sabe o que que eu percebo? Que às vezes você vive a vida que você não sabe nem que ta vivendo a vida... é igualzinha a história da felicidade né... mais que raio de felicidade é essa que nunca que chega, que a gente nunca sabe se ta feliz, se não ta? Aí você começa a dizer “mais não gente... peraí... não é... ou eu to lá pra trás ou eu to lá pra frente... não... eu quero ta aqui agora”... entendeu? Por exemplo: eu agora to aqui com você não to preocupada com coisa nenhuma... do resto eu vou saber depois... entendeu como é que é?

Se valorizar, viver o aqui e agora, viver intensamente, ser feliz, se preocupar apenas com o que lhe diz respeito no momento... Esses são os pontos que ela percebeu mudança em sua vida. Muito interessante e positiva esta sua fala.

Perguntamos em seguida o que ela acha que tem feito para ajudar em seu tratamento:

Eu acho que essa minha postura de... de estar... é... positiva né... e eu vejo, realmente, que isso, também, foi uma coisa que eu detectei... é... que as pessoas... estão dentro de um processo... e elas continuam negativas... por exemplo... você quer ver uma coisa simples? Eu to fazendo lá um laboratório lá... o ratinho lá na caixa de Skinner... eu não... eu tava internada... eu não fiz a primeira... o primeiro trabalho... 
mas quando eu me liguei a esse grupo, eu fiquei sabendo que o ratinho no primeiro dia tinha caído... foi um Deus nos acuda e tal... bom... aí quando... cheguei lá... fui fazer... no rato... aí a menina "ah... porque esse rato caiu... porque esse rato não ta bom... porque esse ato não sei o que..." daí a outra "ah... não vai dar certo... porque não sei o que”... conclusão... foi tanta coisa que o rato foi condicionado de uma forma errada... ele não pressionou a barra... e ele condicionou só cheirar... e aí depois da segunda sessão ou terceira... sei lá... que a gente fez... acho que foi segunda... que aí a professora veio e tal... e a gente até ia ter que... vai fazer uma aula extra... quando ela veio comentar isso e tal... daí eu falei "gente... então vamo mudar... vai trocar o rato"... daí a professora falou "não... não gente... não troque se não vai ter que iniciar tudo de novo... vamos fazer como ta”... daí eu falei "gente... o desafio é esse... então vamos ver o que é que a gente pode melhorar"... aí conversei com ela... "o que é que tem... é isso que tem que fazer? A gente condicionou errado? Ah... ótimo! Então a gente já aprendeu que a gente condicionou errado... então a gente já ta sabendo como é que é... como é que tem que ser esse reforço aí... foi feito errado... vamo mudar... e patatá...... e aí.. hoje... o rato bebeu água lá... belezinha... ele mesmo apertou a barrinha... mas eu tive que fazer um pouco de pressão lá porque... gente... aí por exemplo... to lá esperando... a gente sabe que vai demorar... eu levo meu negócio pra ler... o meu estudo... ou sei lá... tem a televisão que você pode ver... ou vai lá pra enfermeira, bate um papinho... e... porque assim... você arruma o que fazer... porque você vai ter que aguardar... não... não tem como fugir... aí o cara senta do lado e fica assim "a senhora já viu quanto tempo a gente espera aqui?”... eu falei “Já....... “a senhora já viu que absurdo?" "é chato mesmo...... mas... “a senhora sabe que eu já criei caso aqui? Já briguei?”... eu falei "ih... pois eu não... eu venho aqui... eu to passeando... eu venho pra um passeio....... a gente não vai no médico e tem que esperar? Você vai no supermercado, você... pega uma filinha... sempre tem né... então você tem que esperar... até a caixa, quando você põe a coisa lá... pro dinheiro sair... você tem que esperar... aí eu comecei a conversar com ele... porque aquilo ali acaba se tornando um sofrimento... e ontem foi muito engraçado... que ele sabia que era a minha última sessão... ele foi lá na porta pra dizer "escuta... ela hoje tem que entrar na frente de todo mundo... é prioridade... é o último dia dela...... ele já tava lá fazendo discurso... ai todo mundo "não... a gente já vai chamar ela... pode deixar"... e foram embromando e tal... e ele lá... você ta entendendo o que eu to dizendo? Essa coisa... eu acho que isso não ajuda... 
porque... você não tem que fazer aquilo? Você tem uma opção... não fazer... que também não vai ser legal... você vai ficar "ah... eu poderia ter feito... não fiz...... enfim... a não ser quando você está muito mal... você chuta o pau da barraca, como diz na gíria, né... mas caso contrário, você ta ali... né... fazendo o procedimento, que é... o... você tem que fazer... você não tem como... então faça e... da melhor maneira possível... e isso também foi outra coisa que eu percebi... então você... se não estiver atenta... você... você é contaminada por isso... é difícil... é coisa... não dá... e... você ta entendendo? Você se contamina... você se robotiza... e você não sabe de você...

A essência dessa fala seria que se deve fazer o melhor em tudo o que puder para que não se fique robotizado na vida.

Quanto ao envolvimento familiar, ela nos relata o seguinte:

O processo familiar, inicialmente, foi eu e meu marido mesmo... isso é outra coisa muito interessante... porque eu já estou com... vou fazer esse ano vinte e nove anos de casada... então isso aconteceu eu tinha... então eu tava com vinte e sete pra vinte e oito anos de casada... então quer dizer... eu fiz vinte e oito em dezembro... eu já tava dentro do processo né... então é uma fase... que a gente... diria até que o casamento... é... poderia... né... você se condicionou um ao outro né... que passam aquelas emoções... que passam... a gente entre na vida... na rotina... um já conhece o outro... já vira irmão... vira amigo... não tem essas histórias que contam nas famílias... e eu percebi que isso não tinha acontecido comigo... porque a demonstração do meu marido... é... foi assim... é... eu num quero rasgar ceda... porque... eu casei com ele porque eu percebi... percebi nele... e... uma pessoa muito legal... assim... eu acho que o... o companheirismo... e... e... você ser... eu acho que o casamento... tem que ter uma parcela de solidariedade... se não tiver isso, não é relacionamento... porque nós somos diferentes né... então a gente vai viver juntos, mas na realidade, as pessoas são diferentes... e eu vi que realmente ele se... ele se... vamo dizer... ele entrou nesse esquema... pra... me ajudar... de forma incondicional... então, esse primeiro momento, eu fiquei sozinha, só eu e ele... porque meu pais não estavam aqui... é... eu tenho pai e mãe... né... que moram aqui em Brasília... eles tavam no Rio... e também eu achei muito interessante... uma grande proteção... porque eu não poderia dar a assistência a eles que eu dou... porque eu estaria envolvida em exames... então, inclusive com a própria 
cirurgia... Eu tive a notícia no dia vinte e cinco... no dia sete de agosto eu tava indo operar... foi coisa de duas semanas... rápido... agilizei tudo né... e é aí que eu digo pra você... você vai fazer o exame... tem que esperar... então esse... é só paciência e você tem que ter... tem que ter... e outra coisa... eu ainda cheguei no (nome do hospital) passando mal, e ainda tive que assinar papel... aí eu botei o meu marido pra assinar papel porque eu não dava nem conta... entendeu como é que é? É um negócio assim, que não dá pra você entender... você morre mais você tem que assinar o papel... o bendito papel... entendeu... tudo bem... né... que representa o dinheiro... mas... é muito estranho né... mas... e aí o meu marido foi assim... se integrou assim... e num esforço muito grande, porque meu marido detesta médico, detesta hospital, detesta... detesta isso... um dos motivos que eu fiquei sem fazer mamografia, foi... a gente sempre faz exames juntos... sempre faz essas radiografias que precisa... faz essas ecografias prostáticas que ele tem que fazer... mas ele não... depois a gente vai... depois... aí eu falei "gente! Já é julho! Eu vou fazer a minha mamografia, tchau e bença...”... aí marque e tal... entendeu... então ele não... ele podendo, ele foge... então ele fez todas... venceu toda essa... essa dificuldade pra me acompanhar... e tudo... e tal né... inclusive... essa semana que eu fiquei no hospital, ele ficou lá comigo né... ele ficou preocupado porque... é um saco ficar no hospital né... porque, por exemplo, se você ta muito mal... você consegue... fica ali, e tal né... mas se você ta com a cabeça pensante... tudo lá fora correndo... e você ali com aquele soro... com aquele... dois troços... pra ir pro banheiro... você carrega aquilo... e vai... você num... é muito... chato... chato sabe... mas aí você tem que reverter né... e... aí eu conversava com as enfermeiras... tem uma que ficou grávida... tinha ligado as trompas... só faltou o marido... o marido internou... ele entrou em crise... porque o último filho ela teve eclampse... e passou muito mal... quase morreu... e ele ficou... quando teve a notícia, ele ficou tão ruim... que teve aquele problema de depressão e teve que ser internado... e aí ela contando... e eu "me conta mais... depois você volta aí...... aí eu mandei mais pra passar o tempo... e contando as histórias... e querendo saber... e vinha a roupeira... e... tinha... você tem que fazer um folclore... você tem que enfeitar a vida... não é? Tem que enfeitar... tem... tem que aproveitar... então... procurei praticar esse exercício... retornando a papai e mamãe... eu... meu marido falou assim "ta na hora de você falar pros seus irmãos... já ta tudo... ta aí... você vai ter que operar mesmo... e vai ter que manter eles mais informados"... aí minha mãe inventou isso... inventou aquilo... porque no 
dia vinte e cinco eles já estavam no Rio porque meu irmão faz anos... agora eu tenho outro que faz no dia dezenove de agosto... aquele casula que morava nos Estados Unidos... ele tava no Rio... aí, agora ele veio pra cá pro Rio... morar no Rio também... fazendo representações de empresa... e... ele... e aí o meu marido falou "não! Vamo aí...... e ligou pros meus irmãos e... minha irmã foi prendendo eles lá... e... fora até que ela veio com eles pra cá pra poder falar... só que eu não... ela já sabia... minha irmã... meus irmãos também ficaram sabendo porque meu marido falou "não... você tem que falar pra eles... que é pra poder prender seu pai e sua mãe, porque você não vai ter como... você vai ficar sem se mexer... os braços trinta dias... como é que você vai...... aí a minha irmã veio... e eu aí conversei com meus pais e com eles... com um almoço aqui... aí conversei... a minha mãe, logo que me viu na porta... a minha mãe ta com oitenta e quatro anos... então... de vez em quando ela... sai assim um pouquinho do... (risos)... como se diz... do quotidiano né... ela entrou "nossa! Como você ta magra! Você emagreceu!"... porque meu peito tava menor né... ela me achou diferente em alguma coisa ali... né... aí ela falou assim "nossa! Como você emagreceu!" daí eu falei "é, emagreci mesmo....... né... aí... e eu... ainda estava com meu cabelinho graças a Deus... e tal... aí eu só falei "Olha, eu fiz...... aí eu aproveitei a deixa dela... "eu fiz... uma cirurgia... e vou ter que fazer uns procedimentos aí que vão... demorar e tal”... aí... eles não... também não perguntaram... você sabe que o pessoal fica mais... papai com oitenta e dois anos... mamãe com oitenta e quatro... não tem... assim... um raciocínio assim muito rápido né... já não interagem tanto com essa coisa do cotidiano né... eles estavam vindo de viagem e tal... e como se tivesse desligadão né... e aí... o que que aconteceu... simplesmente... o meu irmão casula diz assim "não... não senhora... na bíblia está escrito a verdade vos libertará....... pegou um avião e veio aqui... e falou... "olha... ela está com câncer....... porque eles não quiseram me poupar do que vinha... daí eu falei "olha... vocês fiquem lá porque eu não vou poder dar assistência... vou te que ficar indo no médico... não sei se no fim de semana eu vou ta bem...... aí eu fui falando assim né... porque todo fim de semana eu levo eles pra almoçar... aí vou sair com eles... vou estar com eles... coisa e tal... então... é aquela coisa... fora os extras que tiver durante a semana... aí eles "não... você está mandando... você agora quer coordenar minha vida... quer mandar... voltar a viajar... que vou pro Rio nada....... aí a minha irmã botou a viola no saco e coisa... aí o casula... ótimo né... porque... ele teve lá nos Estados Unidos... é outra cabeça... 
outro universo né... não... não pode ter muitas emoções... tem que ser bem curtas... e raras... e rápidas... e ele aí disse "não... na Bíblia ta escrito a verdade vos libertará... não é isso?"... ainda ficou é sacaneando ainda com o negócio da Bíblia... a... pegou e falou... mas ele... Ele é que contou... mas ninguém é... foi assim... eles, inicialmente, não tiveram... nenhuma reação... mas eu vi que depois a... ao longo da convivência... porque daí eu fiquei careca... eu não fiquei bem... teve dias que eu não pude estar com eles... aí foi que eles ficaram... preocupados... aí ligavam... entendeu... aí você sentiu que... vamos dizer assim... que foi caindo a ficha... entendeu? Mas super solidários... meu pai qualquer artigo que ele ver de câncer, ele manda... ele coisa... e tudo... ele fica assim... sabe... ele não tem... meu pai é muito seco... ele não tem como demonstrar... a minha mãe não... ela já é mais amorosa... mais afetiva... já demonstra e tal... mas... mas eu vejo que dentro da natureza do homem... do meu pai... ele fez o... o máximo... sabe... então eu tive todo o apoio da minha família... meu irmão já veio três vezes aqui me ver... minha irmã me liga sempre... meu outro irmão não vem tanto e... não liga tanto... mas ele... é assim... ligadíssimo... sabe aqueles momentos que eu tive? É... de... de ta vivendo aquele momento mesmo de mal estar... aí ele da aquela ligada... sabe... aquela coisa assim... muito... então eu acho que eu tive assim, muito carinho, muito amor... fora os amigos... eu não tenho do que me queixar não...

Nesta fala, podemos perceber que ela se sentiu bem amparada e acolhida por sua família. Silva (2001) diz que o diagnóstico de uma doença grave exige do paciente e de sua família mudanças de papéis, buscas de estratégias para enfrentar o problema, uma alteração de posturas, atitudes e comportamentos, como também um longo período de adaptações a essas mudanças. No caso dessa família, todos, aparentemente, se envolveram com o câncer. Uns ligando sempre, outros com informações relativas a doença. Ela fecha esta fala dizendo que teve muito carinho e amor de todos.

Passamos em seguida à equipe médica. Foi pedido para que ela contasse como foi o contato com tantos profissionais, se esse contato foi bom, se foi ruim, e, ela responde o seguinte:

Eu tive a notícia pela radiologista... ela me alertou, dizendo que provavelmente eu teria que fazer cirurgia pra pesquisar esse tumor... e que... era uma coisa que eu deveria pesquisar... porque ela estava na dúvida né... ela não falou assim "ah... 
câncer"... mais ela... usou todos os argumentos pra dizer pra mim que... já seria o câncer... né... Foi ótimo porque ela me deu uma incentivada... pra realmente correr atrás... eu aí eu tive... assim... na terça-feira... eu já fiquei sabendo... aí na quinta eu fui buscar a... a radio... a... a... a mamografia... e aí, na sexta eu fui trabalhar... não... nesses dias eu também fui trabalhar... mas aí, na sexta... eu ia trabalhar de tarde...só que aí... um pouco antes... eu que eu queria mostrar a minha chefe a mamografia.. e eu já havia falado com ela... porque todos lá são médicos né... eu trabalho dentro dessa área... e aí eu chegando lá, a doutora tava lá... e aí falou "ué, que que foi? Você fez exame?"... daí eu falei “fiz a minha mamografia”... aí quando ela olhou a minha mamografia... ela aí pegou o telefone e falou "você tem que ir num mastologista, porque você ta com um tumor"... eu falei "não... eu sei... eu trouxe até pra doutora ver... eu vou marcar com o doutor....... daí ela falou assim "não... eu vou ligar agora.......e ela conseguiu... tanto que eu fui ser atendida quase oito horas da noite... no mesmo dia... dali eu já fiz a pulsão... eu nem trabalhei de tarde... já fui direto pro médico... aí o que a doutora falou "não, você não vai sozinha..." aí mandou psicóloga do tribunal ir comigo... na mamografia tem um negócio... com valores diferentes... o meu era cinco... e cinco era tumor maligno mesmo... sabe... essa foi a mesma categoria que a doutora do tribunal fez... então ela já correu comigo... ai o doutor que é meu mastologista... ele já prontamente me atendeu, e tal... e... eu acho que eu... fui bem tratada... não sei se foi porque é pelo lado particular... a gente aí não sabe né... não posso ta julgando... é complicado né... mas, é como eu disse a você... eu sou grata porque eu tive um acesso rápido a tudo... né... ele, por exemplo, veio aqui em casa fazer o curativo, e ele me explicou toda a minha situação... ele me falou "olha, agora você vai para a quimioterapia... a gente não pode deixar de fazer a quimioterapia... se cabelo vai cair... aproveita que ele ta grande e já faz uma peruca..." Ele foi... deixou claro... pra mim, toda a etapa que eu iria vivenciar... e teve comigo sempre... me orientando... depois eu fui pra oncologista... achei ela também fantástica... a doutora foi que e encaminhou... ela também, super atenciosa... e depois ela me encaminhou pra doutora que foi a minha radiologista... então eu não...com relação a essa área médica, eu não... tenho... nada assim... porque... esse mastologista me foi colocado como uma pessoa que cuida de médico... então, você sabe que médico sabe... tem uma noção... né... ele pode não entender muito da área... mas... o médico vai se submeter a quem ele vai achar que tem uma competência para tal... então... eu segui por essa linha né... então... essa área pra mim... eu realmente não tive problema... 
E ela continua, falando sobre o contato com os enfermeiros e técnicos:

...foi excelente... aliás... isso é uma das coisas que eu... fico assim, impressionada né... porque esse lado pessimista da vida... mas você vê pessoas alegres, contentes e satisfeitas... trabalhando todo dia... numa... numa área... e com um pique... eu ficava quase quatro horas esperando... esse pessoal chegava uma hora da tarde, as vezes vão sair uma e meia da manhã... e é... não é uma coisa parada... porque... aquilo você tem que... pra um é uma coisa... tem uma profissão pra ficar lá na maca... entendeu... no meu por exemplo... no seio tem um aparelho pra poder botar o meu braço... então tira, bota... um é na cabeça... o outro, é na...na regia de baixo... enfim... né... toda aquela movimentação da aparelhagem é que... não dá pra você sentar e ficar parado... porque você sabe que tem uma fila lá pra... ta tudo lá esperando... entendeu... então eu achei assim... o comportamento deles é assim... é muito solicito... são... acho que são pessoas realmente que... que... tão ali porque... ao realmente cumprindo alguma coisa... eles têm uma... uma função especial... são pessoas que têm uma função específica para tarem ali... uma natureza... uma coisa especial...

Wanderley (2003), como já citado anteriormente, nos diz que o trabalho da equipe é fundamental, tendo em vista que os médicos e enfermeiros podem informar as pacientes do ponto de vista técnico, contribuindo para o alívio em relação ao câncer. É importante que a enferma tenha participação ativa nos processos de tratamento e controle da moléstia, e os esclarecimentos estariam proporcionando o domínio do paciente sobre o seu corpo, garantindo-lhe melhores condições para assumir as suas atividades; o que parece ter sido o ocorrido. Ela demonstra ter consciência de seu tratamento, parece ter gostado muito da forma como a trataram, pois, se sentiu acolhida, e, em um ambiente bom.

Como ela já vivenciava um ambiente médico, sua visão desses profissionais pode ter sido enviesada. De qualquer forma, é muito interessante a forma como ela retrata esse tratamento profissional. Em um momento ela chega a achar que pode ter sido um tratamento bom porque era particular, mas, ela não se fixa neste argumento.

A visão que fica é que esse tratamento parece ter sido algo bem conjunto. Ela foi bastante ativa, e, aparentemente, soube analisar cada detalhe. Acreditamos que esse tratamento conjunto a tenha ajudado de forma muito positiva a enfrentar todo este processo. 
Para fecharmos o contato com os profissionais de saúde, perguntamos se ela teve contato com mais algum profissional, a fim de saber se ela procurou ou se já fazia terapia. Ela responde o seguinte:

Tive... eu já fazia terapia né... e tive a minha psicóloga acompanhando... eu não tive um contato direto com psicólogo, mas acabei tendo um contato indireto... eu lendo coisas de psicologia e... ela puxou conversa comigo "ah, você é colega... e tal...... e aí nesse coisa a gente... conversou muito... foi muito interessante... foi uma troca muito... bacana... ganhou... eu falei da ekebana e tal... ela me perguntou... então, foi um fato do lado de fora de $\mathrm{m}$ consultório... que ela tava aguardando um paciente... e foi um momento, assim, muito interessante... então, eu acho que todo o ambiente ali é favorável né... as pessoas tão... eu não senti... ninguém, inadequado, no seu papel ali ta... eu achei o pessoal muito legal... não passei por nenhum tipo de constrangimento... nada... nenhum comentário diferente... nada... eu acho que foi tudo maravilhoso...

Sua fala acaba retornando a pergunta anterior, sem se prender ao questionamento que foi feito.

Concluímos, então, esta entrevista, perguntando o que ela pôde tirar de tudo o que aconteceu; se ela pôde concluir coisas boas, ruins etc, para a sua vida de hoje. Ela responde o seguinte:

Olha... que na vida, você vai ter algumas coisas que virão pra você... ruins... mas, que também, elas... tem um lado que você tem que ver... porque nesse mal... você vê coisa boa... e eu tinha esse princípio, dentro da linha da ekebana... né... mas uma coisa é a filosofia... outra, é você vivenciar... e eu pude, realmente vivenciar isso. Porque aí, por exemplo, você vê o médico, me deu uma força... eu já to dentro de uma área médica... então, eu começo a ver todos os privilégios que eu fui contemplada... mas você começa a valorizar tudo... então eu acho que... isso... faz você ficar mais... mais atenta né... a não aquela coisa derrotista né... pessimista né... mas a você valorizar... esse foi um ponto pra mim... é... importante..."

Ela finaliza se reportando, primeiramente, à sua filosofia de vida. Sua prática religiosa parece ter ajudado muito, como já dito anteriormente. Posterior a isso, ala fala do saber esperar e o quanto isso a ajudou a enfrentar cada momento. 
Essas duas entrevistas nos ajudam a perceber que tamanhas são as influências sofridas pelas mulheres diagnosticadas com câncer de mama. Realmente, os diferentes papéis, tanto dos familiares, como dos profissionais de saúde, tiveram impactos importantes nos tipos de enfrentamentos durante todo o tratamento.

\section{Conclusão}

Este estudo teve como finalidade principal o entendimento de como as mulheres portadoras de câncer de mama conseguem reestruturas suas vidas após o choque do diagnóstico, levando-se em conta o apoio familiar e da equipe interdisciplinar no qual fazem acompanhamento. Sabe-se que esse apoio pode influenciar positivo ou negativamente no processo de aceitação e adesão ao tratamento, e, principalmente, no caminho para a cura.

De acordo com as entrevistas realizadas, vê-se importante ressaltar que o modelo de enfrentamento pode sim, ser influenciado tanto pela família quanto pela equipe interdisciplinar. E, toda a história de vida destas pacientes, o contexto em que vivem, os contextos em que receberam seus diagnósticos, tudo, influenciou o modo como essas pacientes perceberam seu câncer, seu tratamento e as influências que sofrem.

Percebem-se, claramente, as diferenças de enfrentamento, aceitação, e, influências sofridas por ambas as participantes. Em uma das entrevistas, pudemos constatar que a falta da família presente fez com que ela vivenciasse cada momento de uma forma mais triste, mais depressiva, enquanto, na outra entrevista, onde a família esteve sempre presente, acolhendo, dando carinho e atenção em todos os momentos, a paciente acabou por vivenciar todo o tratamento de uma forma mais amena, vendo mais os pontos positivos, dando mais valor aos acontecimentos bons. Onde podemos constatar em suas falas que, a paciente que não foi amparada, disse ter chorado muito, se sentindo sozinha, com muito medo de morrer, e, a paciente que participou do contexto contrário, diz ter sentido que era um processo ruim, mas que não se sentiu sozinha, não teve medo de morrer.

Os momentos de recebimento de seus diagnósticos, o contato que tiveram com os profissionais de saúde, também foram bem peculiares. Enquanto uma das 
entrevistadas se vê como uma pessoa de sorte, agradecendo por ter tido contato com profissionais tão humanos, acolhedores e bons naquilo que faziam; a outra entrevistada se vê em dois momentos, onde, em um, os profissionais eram bons porque não iludiam seus pacientes ou, porque se disponibilizavam em outros horários do dia para atendê-la caso fosse preciso, e, num outro momento, o profissional não era bom por induzir a morte quando não vê outra saída, ou, num momento que poderíamos chamar de desumano, quando o médico lhe dá o diagnóstico e a diz que não há nada que se possa fazer, e, quando uma médica a atende sem lhe dar atenção, faz pedido de exames desnecessários, e, diz que terá que pagar nova consulta mesmo sabendo que a consulta já paga não deveria ter acontecido naquele momento.

Essas diferenças de contato com profissionais de saúde, influenciaram de formas diferentes nos tipos de enfrentamento; onde, de um lado, o contato foi motivador por ter sido um contato positivo, e, de outro, não foi desmotivador, porém, não contribuiu tanto para o bom desenvolvimento do prognóstico.

Esse é um estudo que nos faz refletir um pouco mais sobre a influencias que sofremos enquanto pessoas com uma enfermidade crônica. Não podemos generalizar as respostas encontradas neste estudo como verdade absoluta para todas as doenças crônicas, ou, melhor, para todas as mulheres diagnosticadas com câncer de mama. É importante que se prevaleça a individualidade, a subjetividade de cada entrevista. Os sujeitos são únicos, logo, as influencias sofridas, também serão únicas. Cada caso é, realmente, um caso.

\section{As an interdisciplinary team and the family can influence in the treatment of women with breast cancer}

\section{Abstract}

The word "cancer" always was frightful. When it has reference to this illness, then it appears the association to the suffering and the death. The diagnosis of breast cancer has a deep psychosocial impact in the patients and its familiar ones. The anxiety in these families and also in the team to interdisciplinary is high for being the characterized illness as synonymous of the possibility of the- 
rapeutic death and for being the very aggressive one with collateral effect, invasive and stressful change of the auto-image, medical procedures, occurrence of depression and pain. For the accomplishment of this research, interviews had been carried through half-structuralized with two women with breast cancer, being later, transcribing and argued in this study, with the purpose to know the functioning and the characteristics of the relations of these three units (patient, family and hospital team) going deep on the knowledge level that each carrier has of its illness.

Key words: Breast cancer. Woman. Family. Team.

\section{Referências}

AMARAL, M. T. C. Vivenciando o câncer com arte. In: CARVALHO, M. M. M. J. Introdução à psiconcologia. Campinas: LivroPleno, 2003. p. 121-140.

BERGAMASCO, R. B.; ANGELO, M. O sofrimento de descobrir-se com câncer de mama: como o diagnóstico é experienciado pela mulher. Revista Brasileira de Cancerologia, Rio de Janeiro, v. 47, n. 3, p. 277-282, 2001.

CARVALHO, M. M. M. J. O sofrimento da dor em câncer. In: . Introdução à psiconcologia. São Paulo: LivroPleno, 2003. p. 103-120.

CHIATTONE, H. B. C. Urgências psicológicas em leucemia. In: CAMON, V. A. A. Urgências psicológicas no hospital. São Paulo: Pioneira Thompson Learning,, 1998. p. 171-191.

COELHO, M. O. A dor da perda da saúde. In: CAMON, V. A. A. Psicossomática e a psicologia da dor. São Paulo: Thompson Learning, 2001. p. 69-92.

COSTA JR., A. L. Psico-Oncologia e manejo de procedimentos invasivos em oncologia pediátrica: uma revisão de literatura. Psicologia: reflexão e crítica, Porto Alegre, v.12, n. 1, p. 107-118, 1999.

DIAS, M. R.; DURÁ, E. Territórios da psicologia oncológica. Lisboa: Climepsi editores, 2002.

GONZÁlEZ REY, F. L. Personalidade saúde e modo de vida. São Paulo: Thomson Pioneira. 2004. 
As representações sociais como produção subjetiva: seu impacto na hipertensão e no câncer. Psicologia: teoria e prática, São Paulo, v. 8, n. 2, p. 69-85, 2006.

MALDONADO, M. T.; CANELLA, P. Recursos de relacionamentos para profissionais de saúde. Rio de Janeiro: Reichmann \& Afonso Editores, 2003.

MORAES, M. C. O paciente oncológico, o psicólogo e o hospital. In: CARVALHO, M. M. M. J. Introdução à psiconcologia. São Paulo: LivroPleno, 2003. p. 57-64.

RIBEIRO, E. M. P. C. O paciente terminal e a família. In: CARVALHO, M. M. M. J. Introdução à psiconcologia. São Paulo: LivroPleno, 2003. p. 197-218.

SILVA, C. N. Como o câncer (dês) estrutura a família. São Paulo: Annablume, 2001.

VIEIRA, C. P.; QUEIROZ, M. S. Representações Sociais sobre o câncer feminino: vivência e atuação profissional. Psicologia \& Sociedade, São Paulo, v. 18, n.1, p. 63-70, 2006.

WANDERLEY, K. Aspectos psicológicos do câncer de mama In: CARVALHO, M. M. M. J. Introdução à psiconcologia. São Paulo: LivroPleno, 2003. p. 95-102. 